\title{
High Resolution Genomic Profile of Neuro2a Murine Neuroblastoma Cell Line by Array-based Comparative Genomic Hybridization
}

\author{
Jin Hwan Do, In Su Kim ${ }^{1}$, Hyun Myung Ko ${ }^{1}$ and Dong-Kug Choi ${ }^{1} *$ \\ HumanGenome Center,Institute of MedicalScience, University of Tokyo, Tokyo 108-8639,Japan \\ ${ }^{1}$ Departmentof Biotechnology, Konkuk University, Chungju 380-701, Korea
}

Received February 12, 2009 / Accepted March 17, 2009

\begin{abstract}
Murine Neuro-2a (N2a) cells have been widely used for the investigation of neuronal differentiation, trophic interaction and neurotoxic effects of various compounds and their associated mechanisms. N2a cells have many genomic variations such as gains or losses in DNA copy number, similar to other neuroblastoma cells, and no systematic or high-resolution studies of their genome-wide chromosomal aberrations have been reported. Presently, we conducted a systematic genome-wide determination of chromosomal aberrations in N2a cells using a high-throughput, oligonucleotide array-based comparative genomic hybridization (oaCGH) technique. A hidden Markov Model was employed to assign each genomic oligonucleotide to a DNA copy number state: double loss, single loss, normal, gain, double gain and amplification. Unlike most neuroblastoma cells, Mycn amplification was not observed in N2a cells. In addition, these cells showed gain only in the neuron-derived neurotrophic factor (NF), while other neurotrophic factors such as glial line-derived NF and brain-derived NF presented normal copy numbers. Chromosomes 4, 8, 10, 11 and 15 displayed more than 1000 aberrational oligonucleotides, while chromosomes 3, 17, 18 and 19 displayed less than 20. The largest region of gain was located on chromosome 8 and its size was no less than $26.7 \mathrm{Mb}$ (Chr8:8427841-35162415), while chromosome 4 had the longest region of single deletion, with a size of $15.1 \mathrm{Mb}$ (Chr4:73265785-88374165).
\end{abstract}

Key words : Neuroblastoma, chromosomalaberration, Neuro2a, oligonucleotide array-CGH

\section{Introduction}

Neuroblastoma, which is derived from the sympathoadrenal cell lineage of neural crest origin [3], is one of the most common solid tumors of children. Genetic alterations commonly found in these cells include deletion 1p; loss of heterozygosity of $1 \mathrm{p}, 11 \mathrm{q}$ and $14 \mathrm{q}$; and amplification of $\mathrm{N}$-myc [2,15]. Cloned murine neuroblastoma cells have been widely used as a model system for neural cells. In particular, murine Neuro-2a (N2a) cells are frequently used not only to investigate the differentiation and trophic interaction of neuronal cells because of their rapid changes in morphology [13], but also to examine the neurotoxic effects of various compounds and their associated mechanisms $[7,9,18]$. Many characteristics of N2a might be associated with genomic variations such as gain or loss in DNA copy number. However, no publications have reported on chromosomal aberrations of N2a cells, which might bring about the unexpected experimental results or a misinterpretation of experimental

\section{*Corresponding author}

Tel : +82-43-840-3610, Fax : +82-43-840-3872

E-mail : choidk@kku.ac.kr data. The present study aimed, for the first time, to systematically examine the chromosomal aberration of N2a cells in high resolution. Oligonucleotide array-based comparative genomic hybridization (oaCGH) has become a successful and valuable tool for chromosome copy number analysis [16]. Therefore, we examined the chromosomal aberrations of N2a cells with an oaCGH platform from Agilent Technologies (http://www.agilent.com) that consists of 60-mer oligonucleotides synthesized on arrays with approximately $35 \mathrm{~kb}$ resolution. In addition, we analyzed our oaCGH data with a Hidden Markov Model (HMM) consisting of six DNA copy number states: double loss, single loss, normal, gain, double gain and amplification. Most aberrational regions in the N2a genome are composed of single loss or gain of DNA copy number state rather than double loss, double gain or amplification.

\section{Materials and Methods}

\section{Cell culture and DNA extraction}

Neuro-2a (N2a) cells (CCL-131, American Type Culture Collection, VA, USA) were cultured in Dulbecco's Modified 
Eagles Medium (GIBCO, NY, USA) supplemented with 10\% heat-inactivated fetal bovine serum, penicillin (final concentration, $100 \mathrm{U} / \mathrm{ml}$ ), and streptomycin (final concentration, $0.1 \mathrm{mg} / \mathrm{ml}$ ) and maintained in a humidified incubator with $5 \% \mathrm{CO}_{2}$. Genomic DNA was extracted as described previously [5].

Genomic DNA labeling and hybridization to oligonucleotide microarray

For each CGH hybridization, $20 \mathrm{ng}$ of genomic DNA from the reference mouse genomic DNA (Cat.\#G3091, Promega, Madison, WI, USA) and the N2a genomic DNA were amplified with GenomePlex whole genome amplification kit according to the supplier's protocols (Sigma, MO, USA). Briefly, the random fragmentation step was performed by incubating the mixture of 10X fragmentation buffer and genomic DNA sample at $94^{\circ} \mathrm{C}$ for exactly $4 \mathrm{~min}$. The fragmented samples immediately were cooled on the ice. For OmniPlex library preparation, the fragmented samples were mixed with $1 \mathrm{X}$ library buffer and library stabilization solution and then heated at $95^{\circ} \mathrm{C}$ for $2 \mathrm{~min}$. Library preparation enzyme was added into the samples and placed in thermal cycler and incubated as follows; $16^{\circ} \mathrm{C}$ for $20 \mathrm{~min}, 24^{\circ} \mathrm{C}$ for $20 \mathrm{~min}, 37^{\circ} \mathrm{C}$ for $20 \mathrm{~min}, 75^{\circ} \mathrm{C}$ for $5 \mathrm{~min}$, and finally $4^{\circ} \mathrm{C}$ hold. Whole genome amplification (WGA) reaction was carried out in a volume of $20 \mu \mathrm{l}$ with $15 \mu \mathrm{l}$ the OmniPlex library sample, $7.5 \mu \mathrm{l}$ of 10X amplification master mix and 12.5 unit of WGA DNA polymerase. Amplification conditions were the follows; initial denaturation at $95^{\circ} \mathrm{C}$ for $3 \mathrm{~min}, 14$ cycles of $95^{\circ} \mathrm{C}$ for $15 \mathrm{sec}$ and $65^{\circ} \mathrm{C}$ for $5 \mathrm{~min}$, and hold at $4^{\circ} \mathrm{C}$. The amplified samples were purified by using QIAQuick PCR clean-up kit (QIAGEN, CA, USA). Labeling reactions were performed with $5 \mu \mathrm{g}$ of purified amplified DNA and a Bioprime labeling kit (Invitrogen, CA, USA) according to the manufacturer's instructions in a volume of $50 \mu \mathrm{l}$ with a modified dNTP pool containing $120 \mu \mathrm{M}$ each of dATP, dGTP, and dCTP; $60 \mu \mathrm{M} \mathrm{dTTP;} \mathrm{and} 60 \mu \mathrm{M}$ Cy5-dUTP for N2a sample and Cy3-dUTP for the reference sample. Labeled targets were subsequently purified by using QIAQuick PCR clean-up kit (QIAGEN). After checking labeling efficiency, Cy3-labeled and Cy5-labeled DNA targets were mixed and adding 10X blocking solution and $2 \mathrm{X}$ hybridization buffer and human Cot-1 DNA (Applied Genetics, $\mathrm{FL}$, USA) and incubating at $95^{\circ} \mathrm{C}$ for $5 \mathrm{~min}, 37^{\circ} \mathrm{C}$ for $30 \mathrm{~min}$. The labeled targets were directly pipetted onto assembled mouse genome CGH microarray 44K (Agilent Technologies,
CA, USA) containing in situ synthesized 60-mer oligonucleotides for $43,000+$ coding and noncoding mouse sequences. The arrays hybridized at $65^{\circ} \mathrm{C}$ for $40 \mathrm{hr}$ using Agilent Hybridization oven (Agilent Technologies). The hybridized microarrays were washed as the manufacturer's washing protocol (Agilent Technologies).

Image and data analysis

Micorarry slide images were obtained by a GenePix 4200A laser scanner (Axon Instruments, CA, USA) and were saved as a GenePix Result (GPR) format. The GPR files were imported into GeneSpring 7.2 (Agilent, CA, USA) and were normalized by the intensity-dependent "lowess normalization" method. The ratio of $\mathrm{Cy} 5 / \mathrm{Cy} 3$ should theoretically be $0.5(1 / 2)$ for a single loss, $1(2 / 2)$ for the normal state, $1.5(3 / 2)$ for a gain when N2a DNA and reference DNA are labeled by $\mathrm{Cy} 5$ and $\mathrm{Cy} 3$, respectively. In practice, microarray experiments are subject to sources of variation which create noise and bias the theoretical values. To reduce the experimental biases, the average for two replicate arrays was used for our analysis. The sex chromosomes $X$ and $Y$ are excluded in our analysis because the reference genomic DNA was isolated from whole blood of disease-free mice whose sex is unclear. We used a segmental maximum a posteriori approach (SMAP, www.bioconductor.org) to analyze the oaCGH data. The SMAP is an R (www.r-project.org) package developed by Andersson et al. [1] for genome-wide copy number profiling. The SMAP is based on discrete-index Hidden Markov Model (HMM) and incorporates genomic distance and overlap between clones or oligonucleotides. For a given sequence of length $T$ of olionucleotides, which is the total number of oligonucleotides, and the corresponding sequence of observed intensity ratios $O=\left\{o_{1}, \ldots, o_{T}\right\}$, and chromosomal position $P=\left\{p_{1}, \ldots, p_{T}\right\}$, and chromosomal identifiers $C h=\left\{c h_{1}, \ldots, c h_{T}\right\}$, such that $c h_{t} \in\{1, \ldots, C\}(1 \leq t$ $\leq T)$, the most plausible sequence of copy number assignments, $Q=\left\{q_{1}, \ldots, q_{T}\right\}$, is inferred using an HMM which is a pair $H=(S, \lambda)$, where $S=\left\{s_{i}\right\}_{i=1}^{N}$ is a set of N DNA copy number states, such that $q_{t} \in S(1 \leq t \leq T)$, and $\lambda=(\Pi, A, \Omega)$ are parameters for the model. In this study, we employed a six-state model consisting of double loss, single loss, normal, gain, double gain and amplification, i.e. $N=6$. Given a sequence of observations $O$, chromosomal positions $P$ and known parameters $\lambda$, the probability of a certain sequence of copy number assignments can be obtained by the a posterior probability density function (pdf): 


$$
p(Q \mid O, P, \lambda)=\frac{p(Q \mid p, \lambda) p(O \mid Q, P, \lambda)}{p(O \mid P, \lambda)}
$$

where $p(Q \mid P, \lambda)$ is the a prior pdf of the copy number states, $p(O \mid Q, P, \lambda)$ is the likelihood of the observed intensity ratios and $p(O \mid P, \lambda)$ is a normalization constant. Therefore, the most probable sequence of copy number assignments can be inferred by posterior maximization, i.e. $Q^{*}=\arg \max$ ${ }_{Q}[p(Q, O \mid O, \lambda)]$. However, in most cases the parameter $\lambda$ is unknown. Therefore, the SMAP finds the most plausible state sequence $Q^{*}$ by maximizing the joint probability of $Q$ and $\lambda$ given $O$ and $P$ as below

$$
\begin{aligned}
Q^{*} & =\underset{Q}{\arg \max } \max _{\lambda}[p(Q, \lambda \mid O, P)] \\
& =\underset{Q}{\arg \max } \max _{\lambda}[p(Q, O \mid P, \lambda) p(\lambda)] \\
p(\lambda) & =p(\Pi) p(A) p(\Omega)=\prod_{i, j=1}^{N} p\left(a_{i j}^{d}\right) \prod_{i=1}^{N} p\left(\pi_{i}\right) p\left(\mu_{i}\right) p\left(\sigma_{i}\right)
\end{aligned}
$$

where $Q^{*}$ is called the segmental MAP estimate of $Q$. Alternate maximization over $Q, \lambda$ gives a sequence of estimates with non-decreasing values of $p(Q, \lambda \mid O, P)$ for any stating parameter estimate $\lambda^{(m)}[6]$, i.e.

$$
\begin{aligned}
& p\left(Q^{(m+1)}, \lambda^{(m+1)} \mid O, P\right) \geq p\left(O^{(m)}, \lambda^{(m)} \mid O, P\right), \\
& Q^{(m)}=\underset{Q}{\arg \max }\left[p\left(Q, O \mid P, \lambda^{(m)}\right],\right. \\
& \lambda^{(m+1)}=\underset{\lambda}{\arg \max }\left[p\left(Q^{(m)}, O \mid P, \lambda\right) p(\lambda)\right]
\end{aligned}
$$

The SMAP uses the gradient descent method to find the parameters $\lambda$ maximizing the $p\left(Q^{(m)}, O \mid P, \lambda\right) p(\lambda)$. The start chromosomal location for each oligonucleotide is based on the mouse genome database (UCSC mm8, NCBI Build 36).

Validation of DNA copy number aberration from oaCGH data by polymerase chain reaction

To test the reliability of oaCGH data, we carried out a polymerase chain reaction (PCR) against three genomic re- gions showing normal, single loss and gain in N2a cells. The primer sequences and genomic regions are shown (Table 1). PCRs were performed in a total volume of $20 \mu \mathrm{l}$ of ExTaq $^{\text {TM }}$ (Takara, Japan) with $100 \mathrm{ng}$ of the genomic DNA samples isolated from $\mathrm{N} 2 \mathrm{a}$ cells and from reference mice, respectively, a final concentration of 10 pmoles/ $\mu \mathrm{l}$ oligonucleotide primers. The reference mouse genomic DNA was the same as that used in the oaCGH experiment (Cat.\#G3091, Promega, WI, USA). The cycle number of the PCRs was selected to be between the mid-exponential phase and the late-exponential phase increase in DNA copy number. The thermal cycling conditions of the PCRs were as follows: normal and single loss regions, 30 cycles of denaturation at $98^{\circ} \mathrm{C}$ for $10 \mathrm{sec}$, annealing at $60^{\circ} \mathrm{C}$ for $30 \mathrm{sec}$, and extension at $72^{\circ} \mathrm{C}$ for $60 \mathrm{sec}$; gain region, 27 cycles of denaturation at $98^{\circ} \mathrm{C}$ for $10 \mathrm{sec}$, annealing at $60^{\circ} \mathrm{C}$ for $30 \mathrm{sec}$, and extension at $72^{\circ} \mathrm{C}$ for $60 \mathrm{sec}$.

\section{Results}

Genomic variations of murine neuroblastoma N2a cells

We employed a biologically motivated six-state model for DNA copy number, proposed by van de Wiel et al. [16], rather than the conventional three-state model that includes loss, normal and gain to analyze our oaCGH data. The six-state model consists of double loss, single loss, normal, gain, double gain and amplification. In addition, each state is assumed to have a Gaussian distribution. The initial values of mean and standard deviation for each state are given in Table 2.

\begin{tabular}{|c|c|c|c|c|c|c|}
\hline \multirow{2}{*}{$\begin{array}{l}\text { DNA copy number in } \\
\text { N2a cells }\end{array}$} & & \multirow{2}{*}{ Primer sequence $\left(5^{\prime} \rightarrow 3^{\prime}\right)$} & \multirow{2}{*}{ Genomic region covered } & \multirow{2}{*}{$\begin{array}{l}\mathrm{AF}^{\mathrm{a}} \\
(\mathrm{bp})\end{array}$} & \multicolumn{2}{|c|}{ PCR condition } \\
\hline & & & & & $\mathrm{AT}^{\mathrm{b}}\left({ }^{\circ} \mathrm{C}\right)$ & cycles \\
\hline Normal & $\begin{array}{l}\text { forward } \\
\text { reverse }\end{array}$ & $\begin{array}{l}\text { ACTGTGCCTGGTGCTGACAT } \\
\text { CTAGCCTTCCATCCCCTCAG }\end{array}$ & chr13:55461602-55463802 & 587 & 60 & 30 \\
\hline Gain & $\begin{array}{l}\text { forward } \\
\text { reverse }\end{array}$ & $\begin{array}{l}\text { CAAACACCCGCAGCTAAAGA } \\
\text { GCAGTCCAATGATGTGCTACC }\end{array}$ & chr13:112569626-112571826 & 598 & 60 & 27 \\
\hline Loss & $\begin{array}{l}\text { forward } \\
\text { reverse }\end{array}$ & $\begin{array}{l}\text { CCTCCAGTGGTCTTCACCCT } \\
\text { TGAACACCTTGCCTTTGAGC }\end{array}$ & chr13:23429082-23431282 & 554 & 60 & 30 \\
\hline
\end{tabular}
The optimized mean and standard deviation were obtained by adaptation of HMM to oaCGH data in sequential maximum a posteriori probability (SMAP). Prior to chromosomal aberrations of N2a cells, we surveyed the DNA copy number

Table 1. PCR conditions for the amplification of genomic regions showing loss, normal and gain of DNA copy number in N2a cells

$\mathrm{AF}^{\mathrm{a}}$, amplified fragment $(\mathrm{bp}) ; \mathrm{AT}^{\mathrm{b}}$, annealing temperature $\left({ }^{\circ} \mathrm{C}\right)$ 
Table 2. The initial and optimized values of mean $(\mu)$ and standard deviation $(\sigma)$ for each state of DNA copy number

\begin{tabular}{lccccc}
\hline $\begin{array}{c}\text { DNA copy } \\
\text { Number state }\end{array}$ & Initial & Initial & Optimized & Optimized & $\begin{array}{c}\text { Number of } \\
\text { Oligonucleotides* }\end{array}$ \\
\hline 0 (double deletion) & $\mu$ & $\sigma$ & $\mu$ & 0.24 & 0.09 \\
1 (deletion) & 0.15 & 0.1 & 0.63 & 0.13 & 1225 \\
2 (normal) & 0.45 & 0.1 & 0.97 & 0.19 & 30099 \\
3 (gain) & 1 & 0.1 & 1.35 & 0.17 & 7398 \\
4 (double gain) & 1.55 & 0.1 & 1.92 & 0.19 & 102 \\
$\geq 5$ (amplification) & 2.05 & 0.1 & 2.71 & 0.38 & 19 \\
\hline
\end{tabular}

*the number of oligonucleotide belonging to each DNA copy number state after optimization of $\mu$ and $\sigma$.

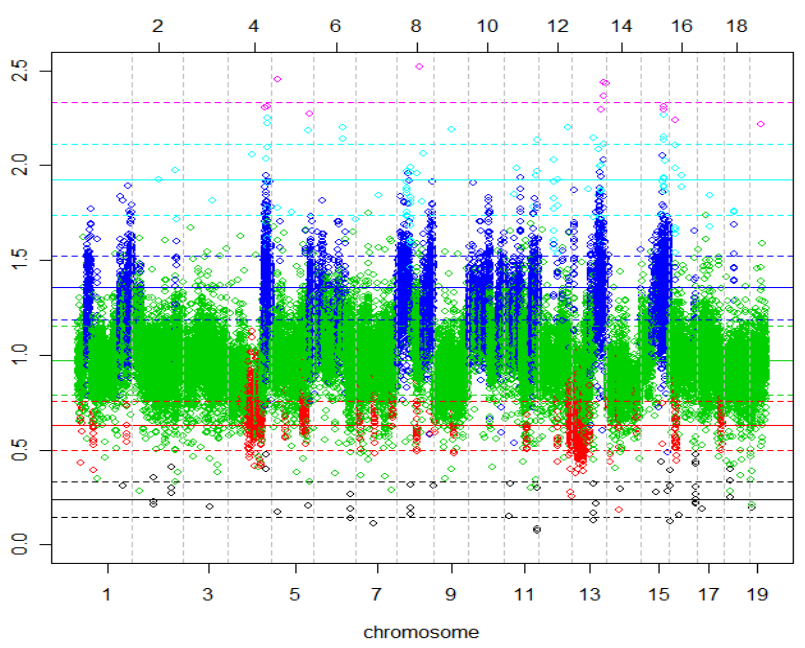

(A)

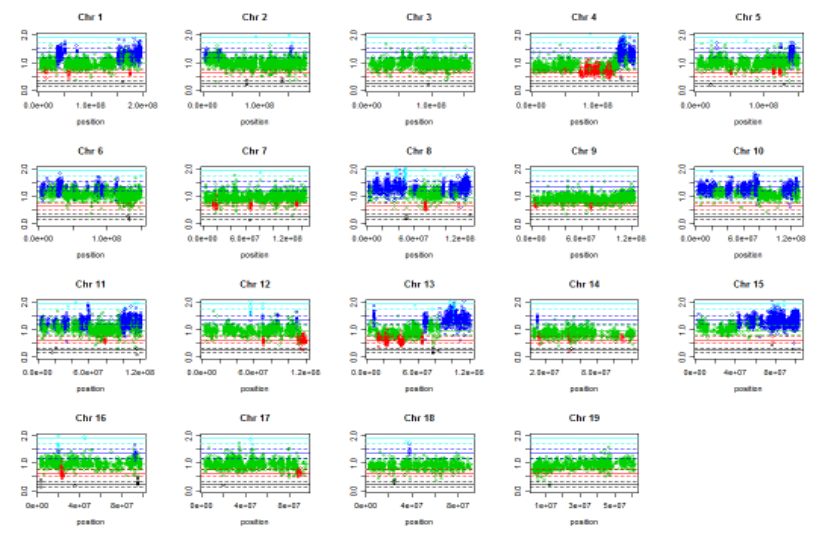

(B)

Fig. 1. The genomic profile of N2a cells with six states of HMM. The six colors represent the six DNA copy number states: black (double deletion), red (single deletion), green (normal), blue (gain), cyan (double gain) magenta (amplification). (A) Whole chromosome profile of oaCGH data. The vertical and horizontal axes represent ratio of N2a DNA to normal DNA and chromosome number, respectively. (B) The profile of oaCGH data in each chromosome over chromosomal location (bp). The vertical and horizontal axes represent ratio of N2a DNA to normal DNA and chromosomal position, respectively.

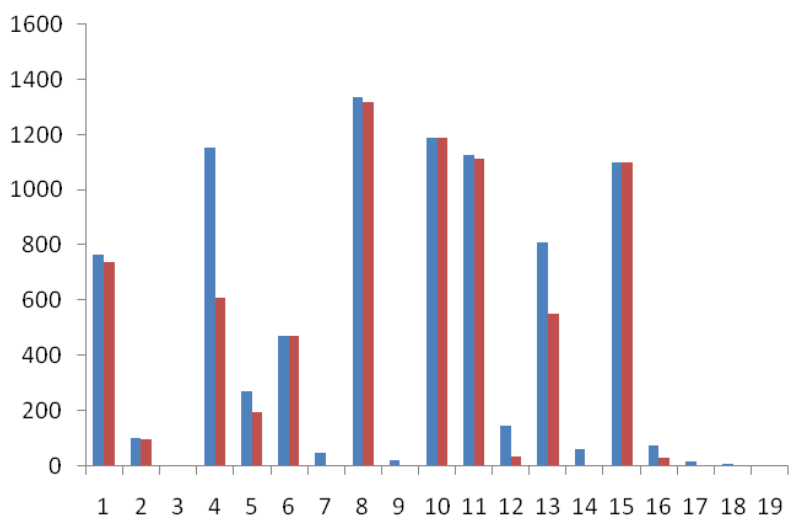

Fig. 2. The distribution of aberrational oligonucleotides in each chromosome. The vertical and horizontal axes represent the number of aberrational oligonucleotide and chromosome number, respectively. The blue color presents the total number of aberrational oligonucleotide, while the red color is the number of oligonucleotides with various gains including gain, double gain and amplification.

aberration of neurotrophic factor (NF) and its receptor in $\mathrm{N} 2 \mathrm{a}$ cells because neural crest-derived cells can be regulated to proliferate or differentiate by neurotrophins including nerve growth factor (NGF), brain-derived neurotrophic factor (BDNF) and neurotrophin-3 (NT-3) via their respective receptors, TRKA, TRKB and TRKC $[4,8,11,14]$. TRKB is frequently expressed in $\mathrm{N}$-myc amplified tumors and may promote tumor cell survival and invasive activity through an autocrine or paracrine mechanism involving BDNF [12]. Neuroblastoma N2a cells showed gain only in neuron-derived neurotrophic factor (NDNF) while GDNF and BDNF presented normal copy number. In addition, the NF-related receptors Ntrk2, Ntrk3, Gfra1, Gfra2, Gfra3 and Gfra4 showed a normal DNA copy number. The amplification of Mycn was also not observed, contrary to most neuroblastomas, but its down-regulated genes Ndrg1 and Ndrg4 showed gain of DNA copy number. Similar to many cancer cells or immortalized cell lines, N2a cells display a loss of 
suppressor genes like Hrasls3 (NM_139269) and gain of oncogenes such as Rabl2a (NM_026817).

The genomic profile of N2a cells are shown in Fig. 1. The six colors used represent the six states in DNA copy number: black (double loss), red (single loss), green (normal), blue (gain), cyan (double gain) and magenta (amplification). The number of oligonucleotides showing aberrations in DNA copy number was 8796 , which constituted $23 \%$ of the total oligonucleotides studied. Ninety-eighty percent of aberrational oligonucleotides belonged to single loss or gain and $85 \%$ were associated with various gain states in DNA copy number (Table 2). Chromosomes 4, 8, 10, 11 and 15 had more than 1000 aberrational oligonucleotides, while chromosomes 3, 17, 18 and 19 displayed less than 20 (Fig. 2). For a clearer representation of DNA copy number states in each chromosomal location, we plotted the profile of DNA copy number state for each chromosome (Fig. 3). The largest region of gain was located on chromosome 8 and its size was no less than 26.7 Mb (Chr8:8427841-35162415), while chromosome 4 had the longest region of single deletion with a size of $15.1 \mathrm{Mb}$ (Chr4:73265785-88374165) (Table 3). The number of oligonucleotides with a single loss in chromosomes 4, 5, 13 and 16 ascended to more than $30 \%$ of the total aberrational oligonucleotides on each chromosome, in contrast to chromosomes $1,2,6,8,10,11$ and 15, which had mainly gain of chromosomal aberration (Figs. 2 and 3 ).

Confirmation of oaCGH data by polymer chain reaction

To test the reliability of the oaCGH data, we conducted polymerase chain reaction (PCR) to amplify three genomic regions that had displayed normal, single deletion and gain in oaCGH data. As the ratio of a single oligonucleotide (spot) in oaCGH data provides a representative value for the ap-
Chr 1

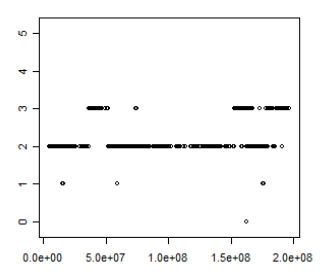

Chr 6

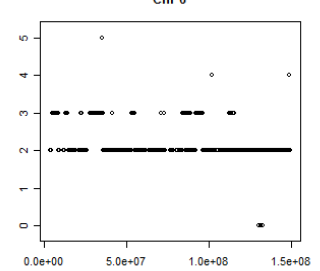

Chr 11

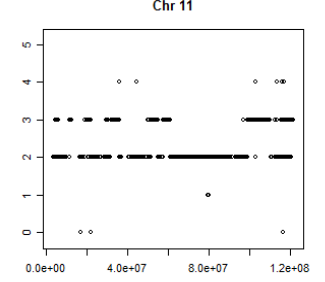

Chr 16

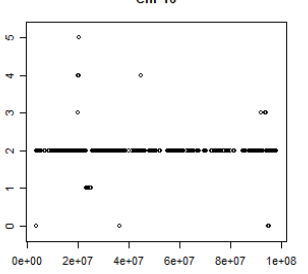

Chr 2

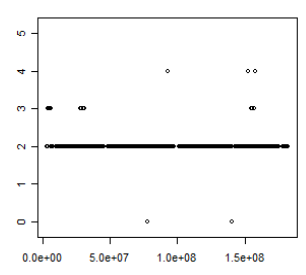

$\mathrm{Chr} 7$

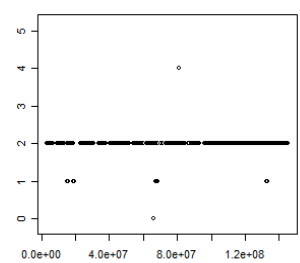

Chr 12

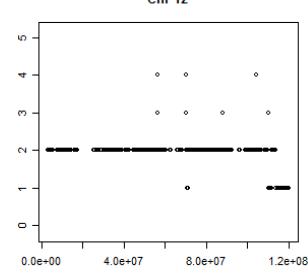

Chr 17

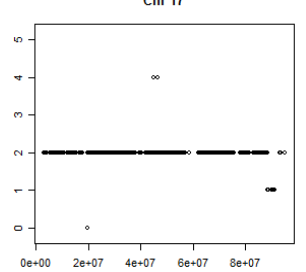

Chr 3

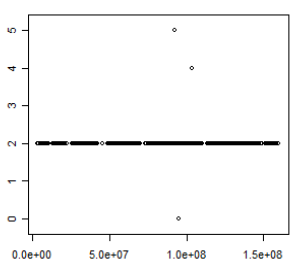

Chr 8

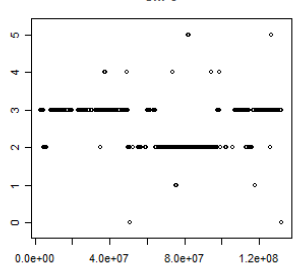

Chr 13

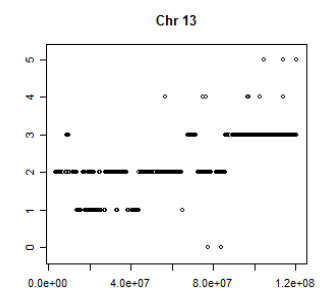

Chr 18

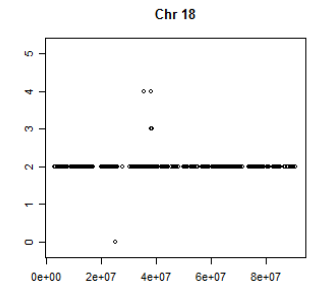

Chr 4

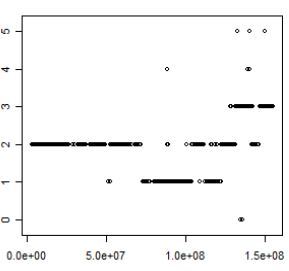

Chr 9

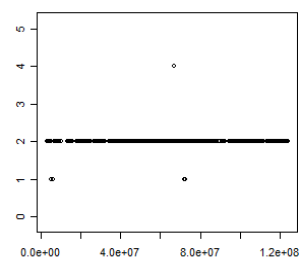

Chr 1

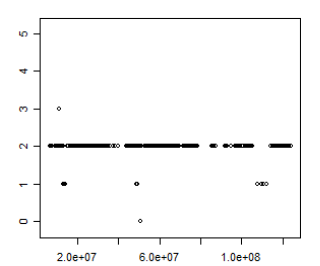

Chr 19

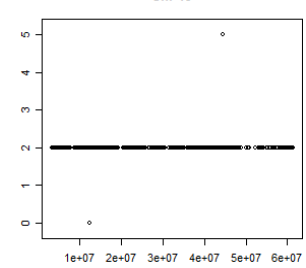

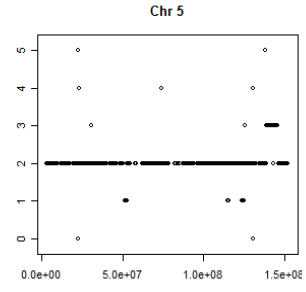

Chr 10

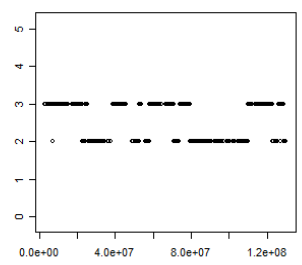

Chr 15

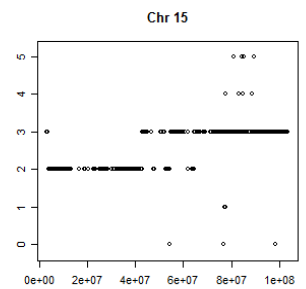

Fig. 3. Copy number state profile for each chromosome. The vertical and horizontal axes represent the copy number state and chromosomal location (bp), respectively. The DNA copy number states $0,1,2,3,4,5$ and 6 represent double loss, single loss, normal, gain, double gain and amplification of DNA copy number, respectively. 
Table 3. The chromosomal aberrational regions with same DNA copy number state over long range $(\geq 1 \mathrm{Mb})$

\begin{tabular}{|c|c|c|}
\hline Chromosome & \multicolumn{2}{|c|}{ Chromosomal location (size (Mb), DNA copy number state) } \\
\hline 1 & $\begin{array}{l}\text { Chr1:14870952-15875335 }(1.0,1), \\
\text { Chr1:152827844-158303332 }(5.5,3), \\
\text { Chr1:165886030-167428847 }(1.5,3), \\
\text { Chr1:185682037-190709390 }(5.0,3)\end{array}$ & $\begin{array}{l}\text { Chr1:36210559-52046369 }(16.0,3), \\
\text { Chr1:159379583-161967580 (2.6, 3), } \\
\text { Chr1:179515258-183658644 }(4.1,3), \\
\text { Chr1:190996460-196871859 }(5.9,3)\end{array}$ \\
\hline 2 & Chr2:3624394-6122470 $(2.5,3)$ & \\
\hline 4 & $\begin{array}{l}\text { Chr4:51198419-52745230 }(1.5,1), \\
\text { Chr4:89617858-100792040 }(11.2,1), \\
\text { Chr4:112125091-116244795 }(4.1,1), \\
\text { Chr4:118698044-119799028 }(1.1,1), \\
\text { Chr4:131837732-139001915 (7.2, 3), } \\
\text { Chr4:146666967-149827601 (3.2, 3), }\end{array}$ & $\begin{array}{l}\text { Chr4:73265785-88374165 }(15.1,1), \\
\text { Chr4:101149548-104267925 }(3.1,1), \\
\text { Chr4:116652861-118477303 }(1.8,1), \\
\text { Chr4:120201872-122695521 }(2.5,1), \\
\text { Chr4:139123537-140192396 }(1.1,3), \\
\text { Chr4:149849372-155028976 (5.2, 3) }\end{array}$ \\
\hline 5 & Chr5:138742968-142911467 (4.2, 3), & $143276190-145704260(2.4,3)$ \\
\hline 6 & $\begin{array}{l}\text { Chr6:4475810-8580530 (4.1, 3), } \\
\text { Chr6:53165457-54437239 }(1.3,3), \\
\text { Chr6:91664951-96014807 }(4.3,3),\end{array}$ & $\begin{array}{l}\text { Chr6:27568619-34703935 }(7.1,3), \\
\text { Chr6:83919758-85343104 }(1.4,3), \\
\text { Chr6:112432425-113681877 }(1.2,3)\end{array}$ \\
\hline 8 & $\begin{array}{l}\text { Chr8:3151837-4524923 (1.4, 3), } \\
\text { Chr8:35218222-37146622 }(1.9,3), \\
\text { Chr8:60180098-64448714 (4.3, 3), } \\
\text { Chr8:106979517-112888491 (5.9, 3), } \\
\text { Chr8:116576103-125956454 (9.4, 3), }\end{array}$ & $\begin{array}{l}\text { Chr8:8427841-35162415 }(26.7,3), \\
\text { Chr8:37930642-48936608 }(11.0,3), \\
\text { Chr8:97476541-98684517 (1.2, 3), } \\
\text { Chr8:113662285-114647390 (1.0, 3), } \\
\text { Chr8:126120139-131912936 (5.8, 3) }\end{array}$ \\
\hline 9 & Chr9:5302346-6418030 $(1.1,1)$ & \\
\hline 10 & $\begin{array}{l}\text { Chr10:3051921-6867084 (3.8, 3), } \\
\text { Chr10:24284285-25300016 }(1.0,3), \\
\text { Chr10:57942136-70788595 }(12.8,3), \\
\text { Chr10:110126294-122602508 }(12.5,3),\end{array}$ & $\begin{array}{l}\text { Chr10:7281921-22529882 }(15.2,3), \\
\text { Chr10:38612811-45612119 }(7.0,3), \\
\text { Chr10:74090487-79470491 }(5.4,3), \\
\text { Chr10:127212252-128570992 }(1.4,3)\end{array}$ \\
\hline 11 & $\begin{array}{l}\text { Chr11:18862572-20138380 }(1.3,3), \\
\text { Chr11:31710004-35733852 }(4.0,3), \\
\text { Chr11:57297784-60605786 }(3.3,3), \\
\text { Chr11:102815548-110114229 }(7.3,3),\end{array}$ & $\begin{array}{l}\text { Chr11:20594189-21686646 }(1.1,3), \\
\text { Chr11:51463693-55037352 (3.6, 3), } \\
\text { Chr11:98797852-102703982 }(3.9,3), \\
\text { Chr11:120605270-121652569 }(1.0,3)\end{array}$ \\
\hline 12 & Chr12:110296986-111773850 $(1.5,1)$, & Chr12:114361459-119905025 $(5.5,1)$ \\
\hline 13 & $\begin{array}{l}\text { Chr13:13843491-15810835 }(2.0,1), \\
\text { Chr13:22059672-24623650 }(2.6,1), \\
\text { Chr13:38146972-43566130 }(5.4,1), \\
\text { Chr13:85668336-96802597 }(11.1,3), \\
\text { Chr13:102802057-113844080 }(11.0,3),\end{array}$ & $\begin{array}{l}\text { Chr13:17667293-19158261 }(1.5,1), \\
\text { Chr13:25064128-27356432 }(3.0,1), \\
\text { Chr13:67340620-71351933 }(4.0,3), \\
\text { Chr13: } 97497472-102048867(4.6,3), \\
\text { Chr13:114284416-120556883 }(6.3,3)\end{array}$ \\
\hline 14 & Chr14:12969090-14243791 $(1.3,1)$ & Chr14:107693618-112289290 $(4.6,1)$ \\
\hline 15 & $\begin{array}{l}\text { Chr15:42908270-46489830 }(3.6,3), \\
\text { Chr15:54539781-61783521 }(7.2,3), \\
\text { Chr15:77424795-82979015 }(5.6,3), \\
\text { Chr15:85069288-88519703 }(3.5,3),\end{array}$ & $\begin{array}{l}\text { Chr15:50487545-52165659 }(1.7,3), \\
\text { Chr15:64489112-76543576 }(12.1,3), \\
\text { Chr15:83281940-84383682 }(1.1,3), \\
\text { Chr15:89480001-103393017 }(14.0,3)\end{array}$ \\
\hline 16 & Chr16:23024872-25337641 $(2.3,1)$ & \\
\hline 17 & Chr17:88441369-91140858 $(2.7,1)$ & \\
\hline
\end{tabular}

The DNA copy number states $0,1,2,3,4,5$ and 6 represent double loss, single loss, normal, gain, double gain and amplification of DNA copy number, respectively. The regions with losses in DNA copy number are marked with gray background.

proximately $35-\mathrm{kb}$ genomic region, we chose the genomic regions for the PCR test from copy number stable genomic region that maintains the same state of DNA copy number in long range $\geq 1 \mathrm{Mb}$. In addition, all test genomic regions were selected from the same chromosome with both loss and gain aberrations for the clear representation of chromosomal imbalance. The primer sequences and genomic regions are shown in Table 1. The included genes on each region were Gprk6 (normal region), Abt1 (single deletion region) and Gpbp1 (gain region). The difference of the initial amount 


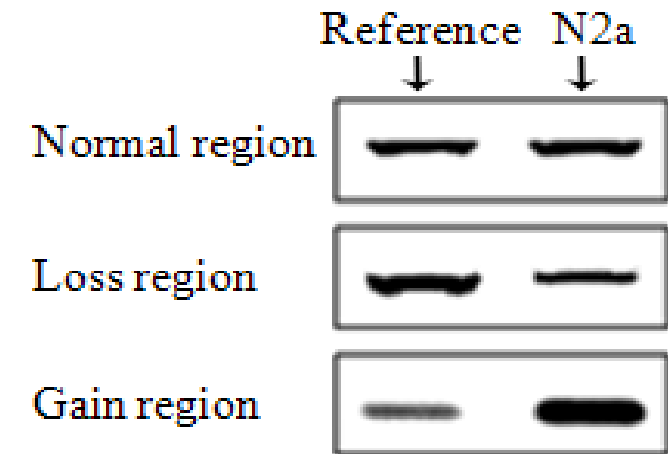

Fig. 4. Comparison of PCR product quantities for three genomic regions in N2a DNA and normal mouse (reference) DNA examined by gel electrophoresis.

of DNA or DNA copy number would make the amount of PCR end-product different and simply identified by agarose gel electrophoresis. There was no change in the quantity of PCR end-product for normal region, but a marked change in the amount of PCR end-product was observed in the regions with DNA copy number aberrations (Fig. 4). The quantity of PCR end-product derived from N2a genomic DNA in the gain region was greater than that obtained from normal mouse genomic DNA, while the quantity of the PCR end-products in the single loss region was much less than normal mouse DNA. This result is a good agreement with oaCGH data.

\section{Discussion}

Presently, we surveyed chromosomal aberrations of N2a cells in genome-wide high-resolution study using microarray-based technique with HMM. Many regions with chromosomal imbalances were successfully identified in N2a cells. For example, chromosomes 4, 8, 10, 11 and 15 had more than 1000 aberrational oligonucleotides, while chromosomes 3, 17, 18 and 19 had less than 20. The total size of genomic regions with losses was $74.9 \mathrm{Mb}$, while the overall size of genomic regions with gains was $322.3 \mathrm{Mb}$. However, it is conceivable that the chromosomal aberrations could be due, in part, to strain difference. Mouse genomic DNA obtained from Promega (Madison, WI) was used as reference; it was not clear whether this genomic DNA was from the same strain as that used for establishing N2a. Furthermore, the $X$ and $Y$ chromosomes have not been evaluated because the reference genomic DNA was isolated from whole blood of disease-free mice whose sex was unclear. The genotype of different strains, including copy number of specific genomic segments, might be different. In any event, these oaCGH datas might provide clues for studies of neuroblastoma biology and neurotoxic effects. We reported previously the chromosomal aberrations in the SH-SY5Y [5], in which the genomic region including PNPLA6, i.e. NTE (19p13.3 19p13.2), showed a normal copy number. However, the PNPLA6 in N2a cells (8qA1.1, Chr8:3515425- 3544266) showed gain in DNA copy number in this study (Table 3). It is interesting to note that there are symptomatic differences of organophophate-induced neurotoxicity between neuroblastoma N2a cells and neuroblastoma SH-SY5Y cells [10]. This might be related to difference in DNA copy number of neuropathy target esterase (NTE) between two genomes because a physiological substrate of NTE is bound by organophosphates that cause a delayed neuropathy in humans and some animals. Pathophysiological and drug development studies with neuroblastoma N2a cells might require cautious elucidation and further study taking genome variations into consideration.

\section{Acknowledgement}

This paper was supported by Konkuk university in 2006 .

\section{References}

1. Andersson, R., C. E. Bruder, A. Piotrowski, U. Menzel, H. Nord, J. Sandgren, T. R. Hvidsten, T. Diaz de Ståhl, J. P. Dumanski, and J. Komorowski. 2008. A segmental maximum a posteriori approach to genome-wide copy number profiling. Bioinformatics 24, 751-758.

2. Aoyama, M., K. Asai, T. Shishicura, T. Kawamoto, T. Miyachi, T. Yocoi, H. Togari, Y. Miura, T. Kato, and A. Nakagawara. 2000, There are different expressions of BDNF and its variants between human neuroblastoma with favorable prognoses and with unfavorable prognoses. Soc. Neurosci. Abstr. 26(Part 2), 2120.

3. Brodeur, G. M. , C. Azar, M. Brother, J. Hiemstra, B. Kaufman, H. Marshall, J. Moley, A. Nakagawara, R. Saylors, N. Scavarda, S. Schneider, J. Wasson, P. White, R.Seeger, T. Look, and R. Castleber. 1992. Neuroblastoma: Effect of genetic factors on biology and treatment. Cancer 70, 1685-1694.

4. Chao, M. V. 1992. Neurotrophin receptors: a window into neuronal differentiation. Neuron 9, 583-593.

5. Do, J. H. , I. S. Kim, T. K. Park, and D. K. Choi. 2007. Genome-wide examination of chromosomal aberrations in neuroblastoma SH-SY5Y cells by array-based comparative genomic hybridization. Mol. Cells 24, 105-112.

6. Gauvain, J. L. and C. H. Lee. 1992. MAP estimation of con- 
tinuous density HMM: theory and applications. In DARPA Sp. And Nat. Lang. Workshop. Harriman, New York.

7. Johnson, V. J., S. H. Kim, and R. P. Sharma. 2005. Aluminum-maltolate induces apoptosis and necrosis in neuro-2a cells: potential role for p53 signaling. Toxicol. Sci. 83, 329-339.

8. Konger, P., G. Barbany, C. Dominici, M. A. Castello, G. Raschella, and H. Persson. 1993. Coexpression of messenger RNA for TRK protooncogene and low affinity nerve growth factor receptor in neuroblastoma with favorable prognosis. Cancer Res. 53, 2044-2050.

9. Lepage, K. T., R. W. Dickey, W. H. Gerwick, E. L. Jester, and D. Murray. 2005. On the use of neuro-2a neuroblastoma cells versus intact neurons in primary culture for neurotoxicity studies. Crit. Rev. Neurobiol. 17, 27-50.

10. Li, X. -H., D. X. D. -X. Long, W. Li, and Y. -J. Wu. 2007. Different mechanisms of lysophosphatidylcholine-induced Ca2+ mobilization in N2a mouse and SH-SY5Y human neuroblastoma cells. Neurosci. Lett. 424, 22-26.

11. Nakagawara, A., M. Arima, C. G. Azar, N. J. Scavarda, and G. M. Brodeur. 1992. Inverse relationship between trk expression and N-myc amplification in human neuroblastomas. Cancer Res. 52, 1364-1368.
12. Nakagawara, A., C. G. Azar, N. J. Scavarda, and G. M. Brodeur. 1994. Expression and function of TRK-B and BNDF in human neuroblastomas. Mol. Cell Biol. 14, 759-767.

13. Sakaguchi, M., K. Murayama, K. Yabe, M. Satoh, M. Takeuchi, and E. Matsumura. 1998. Beta-casomorphin-5 stimulates neurite outgrowth in a mouse neuroblastoma cell line (Neuro-2a). Neurosci. Lett. 251, 97-100.

14. Snider, W. D. 1994. Functions of the neurotrophins during nervous system development: what the knockouts are teaching us. Cell 77, 627-638.

15. Tonini, G. P. 1993. Neuroblastoma: The result of multistep transformation? Stem Cells 11, 276-282.

16. van de Wiel, M. A., K. I. Kim, S. J. Vosse, W. N. van Wieringen, S. M. Wilting, and B. Ylstra. 2007. CGHcall: calling aberrations for array CGH tumor profiles. Bioinformatics 23, 892-894.

17. Ylstra, B., P. van den Ijssel, B. Carvalho, R. H. Brakenhoff, and G. A. Meijer. 2006. BAC to the future! or oligonucleotides: a perspective for micro array comparative genomic hybridization (array CGH). Nucleic Acids Res. 34, 445-450.

18. Zhang, X., A. S. Vincent, B. Halliwell, and K. P. Wong. 2004. A mechanism of sulfite neurotoxicity: direct inhibition of glutamate dehydrogenase. J. Biol. Chem. 279, 43035-43045.

\section{초록 : 고집적어레이 기반의 비교유전체보합법 $(\mathrm{CGH})$ 을 통한 신경아세포종 Neuro2a 세포의 유전체이상 분석 \\ 도진환김인수 $·$ 고현명'최동국 * \\ (일본 동경대학 인간유전체센터, ${ }^{1}$ 건국대학교 생명과학부 생명공학과)}

신경아세포종은 미분화된 신경외배엽 세포로부터 유래한 신경능세포에 의해 형성된 소아기에 보는 가장 많이 발생하는 악성 종양 중 하나이다. 신경아세포종인 Neuro-2a 세포는 신경세포의 분화, 세포사 억제 효능, 세포독성 검정 등에 활용되고 있다. Neuro-2a 역시 다른 신경아세종과 같이 염색체 변이를 가지고 있지만, 이에 대해 고밀도의 게놈수준에서 염색체 변이에 대해 보고된 바가 없다. 본 연구에서는 고집적 마이크로어레이(최소 43,000 개의 코딩, non-코딩 유전자 서열이 집적된 마이크로어레이)기반의 비교유전체보합법을 활용하여, 고해상도의 Neuro-2a 유전 체 이상을 분석하였다. 마이크로 어레이 데이터는 Hidden Markov Model을 활용하여, 유전체 변이를 double loss, single loss, normal, single gain 그리고 amplification으로 나누어 분석하였다. Neuro2a는 MYCN 유전자의 증폭은 관찰되지 않았고, $\mathrm{GDNF}, \mathrm{BDNF}, \mathrm{NENF}$ 등의 neurotrophic factor 가운데 NENF의 gain 현상이 관찰 되었다. 염색체 의 이상은 4,8,10,11,15번에서 발견되었으며, 염색체 3,17,18,19에서는 전부 20 개 미만의 염색체 이상이 발견되었다. 염색체 이상이 연속적으로 일어난 부위 중 gain으로서 가장 긴 부분은 Chr8:8,427,841-35,162,415의 약 $26.7 \mathrm{Mb}$ 이며, single loss로서 가장 긴 곳은 Chr4:73,265,785-88,374,165의 약 $15.1 \mathrm{Mb}$ 였다. 염색체의 위치는 UCSC 데이터베이스 (UCSC mm8, NCBI Build 36)에 근거하였다. 